\title{
PROFILES OF POLYBROMINATED DIPHENYL ETHERS IN AQUATIC BIOTA
}

\author{
Ott ROOTS ${ }^{1,2}$, Vladimir ZITKO ${ }^{3}$, Hannu KIVIRANTA4, and Panu RANTAKOKKO ${ }^{4}$ \\ Estonian Environmental Research Institute ${ }^{1}$,Estonian Marine Institute, University of Tartu ${ }^{2}$, Tallinn, Estonia, \\ St. Andrews, Canada ${ }^{3}$, National Public Health Institute, Kuopio, Finland ${ }^{4}$
}

Received in April 2008

Accepted in July 2008

\begin{abstract}
The profiles (concentrations scaled to a sum of 100) of polybrominated diphenyl ethers (PBDEs) in aquatic fauna differ from those of the commercial PBDE formulations, particularly by a much higher proportion of the congener 47 . At the same time, the profiles reported by different authors vary a great deal and no patterns related to species, localities, etc. are obvious. It seems that there are systematic differences among the reporting laboratories, and measurement errors within the same laboratory may also play a role. However, the profiles of PBDEs in fish from the Baltic are very similar and form a tight "cluster". PBDE profiles in crustaceans appear different from those in fish.
\end{abstract}

KEY WORDS: Baltic Sea, crustaceans, Great Lakes, fish, PBDE, PBDE-47

Five polybrominated diphenyl ethers (PBDEs) are the most commonly measured in aquatic biota: 2,2',4,4'-tetra (PBDE-47), 2,2',4,4',6-penta (PBDE100), 2,2',4,4',5- penta (PBDE-99), 2,2',4,4',5,6'-hexa (PBDE-154), and 2,2',4,4',5'-hexabromo diphenyl ether (PBDE-153). Several authors also reported the concentrations of 2,4,4'-tribromo diphenyl ether (PBDE-28) and of 2,3',4,4'- tetrabromo diphenyl ether (PBDE-66). Several other PBDEs were also reported in a few papers, but their concentrations ranged from undetectable to very low, and are not included in this study. Both the concentrations and the profiles (sum of concentrations scaled to 100) of PBDEs vary widely.

This paper examines the patterns of the profiles of the most frequently reported five PBDEs, of seven PBDEs reported in three papers, and of four PBDEs reported by two laboratories for lake trout and walleye from the Great Lakes.

\section{MATERIALS AND METHODS}

In 2006, the concentrations and composition profiles (concentrations in \%) of PBDEs were first determined in Estonian fish and food (1). Samples of wild fish were collected from the Baltic Sea. Samples were extracted, defatted, fractionated, purified, and analysed for 16 PBDEs. The analyses were performed using a Hewlett Packard 6890 gas chromatograph (GC) and an Autospec Ultima high-resolution mass spectrometer (HRMS). The Laboratory of Chemistry within the National Public Health Institute Department of Environmental Health is an accredited testing laboratory (No. T077) in Finland (current standard: EN ISO/IEC 17025). The scope of accreditation includes PCDD/Fs, non-ortho PCBs, mono-ortho- and other PCBs, and PBDEs from environmental samples. Fish oil is used as an internal quality control sample in the laboratory, and random intralaboratory error for the sum of PBDEs is $4.3 \%$ (2).

PBDE profiling was based on Principal Component Analysis (PCA) carried out using the PLS_Toolbox 2 (Eigenvector Research, Inc., www.eigenvector.com) in Matlab 5.0 (The Mathworks, Inc., www.mathworks. com). PCA introduces new variables, "principal components", which are linear combinations of PBDE congener concentration in the profiles. The principal 
components (pc-1, pc-2, pc-3, etc.) are selected by PCA in a way which retains most of the information of the original data. Thus, most of the information contained in the PBDE profiles usually belongs to the first few principal components (pc-1 to pc-3). This allows visual inspection of similarities (similar pc values) and differences (different pc values) of the multi-(four, five or seven)-dimensional data. Consequently, the transformed data can be viewed in the planes of the principal components ("score plots", see ref. 3). The effects of individual PBDE congeners on the principal components are shown in "loading plots", in which, for example, "ev-1" and "ev-2" show the effects of PBDE congeners on "pc-1" and "pc-2", respectively.

\section{RESULTS AND DISCUSSION}

For the five-dimensional (five PBDEs) data, most of the pattern is visible from the plane of the first two principal components, which capture $(42+28=70) \%$ of the variation of the original data, as indicated on the axes (Figure 1). The third principal component captures an additional $19 \%$ of the original variation and does not change the conclusions reached from the first two principal components. In Figure 1, black squares are data taken from Roots et al. (1) and those found by Zitko (4). The triangles are data calculated from Parmanne et al. (5). Profiles of commercial PBDE formulations, as reported by La Guardia (6), and as quoted by Zitko (4) are indicated by " $x$ ". The data for "miscellaneous fish" are from Voorspoels et al. (7), from a review by Zitko (4), from Hites (8), Zhu and Hites (9), Minh et al.(10), Montory and Barra (11), des Jardines and Mac Rae (12), and Hajšlová et al. (13).

Figure 1 shows that the PBDE profiles of the Baltic fish form a relatively compact cluster among the profiles of miscellaneous fish. The PBDE profiles of the commercial PBDE formulations also form a cluster different from the profiles found in fish. According to the "loading plot" (Figure 2), profiles with a high level of PBDE-47 have high values of pc-1. Conversely, those with high levels of PBDEs 99, 153, and 154 have low values of pc-1. PBDEs 100 and 154 have high, and PBDEs 47 and 99 low values of pc-2. For illustration, Table 1 shows the PBDE profiles of the four extreme samples, from 12 clockwise .

Figure 3 shows expanded PBDE profiles of the Baltic fish $(1,4,5)$. Samples H1-H3, H5, S5, S6, E1, E2, and L1-L3 are herring, sprat, eel, and lamprey

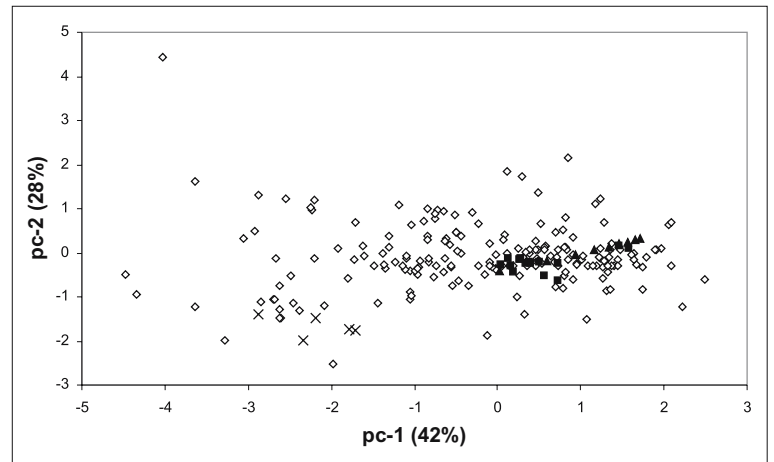

Figure 1 Projection of the profiles of PBDEs 47, 100, 99, 154, and 153 on the plane principal components pc-1 E pc-2 ("score plot"). Fractions of the original variation, captured by the principal components are shown on the axes. The symbols indicate: $\checkmark$ miscellaneous fish, $\mathbf{- B a l t i c}$ fish, $\mathbf{\Delta}$ calculated profiles of PBDE in herring of different ages (5), and $x$ commercial PBDE formulations.

(1), respectively. B are PBDE profiles of the wild Baltic salmon, found by Zitko (4). The numbers are PBDE profiles of the Baltic herring 2 to 10 years old, calculated from the data of Parmanne et al. (5). The latter show that the proportion of the PBDE-47 increases with age of the herring since higher PBDE 47 proportions are reflected in higher values of pc-1 (see Figure 2).

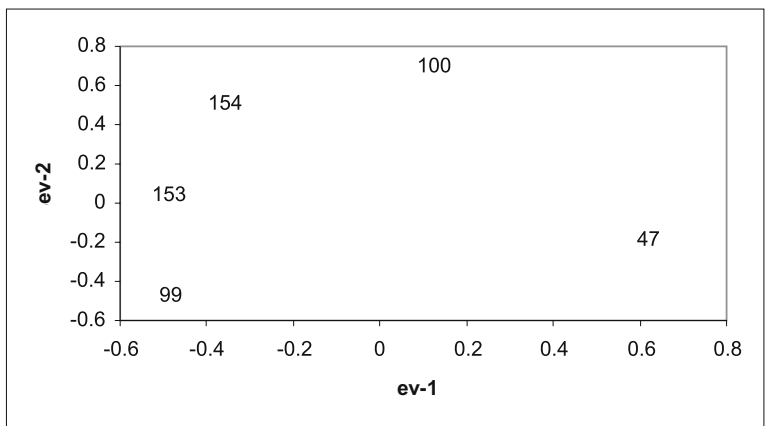

Figure 2 Effects of individual PBDEs on the principal components pc-1 (ev-1) and pc-2 (ev-2) ("loading plot”).

A large amount of data on PBDEs in fish from Californian coastal waters was published recently (14). The projections of their PBDE profiles, together with those of miscellaneous fish in Figure 1, are presented in Figure 4. It can be seen that the PBDE profiles of most of the fish from California are richer in PBDE-47 than those from the Great Lakes and other countries.

Roots et al. (1), Zhu and Hites (9), and Bodin et al.(15) also report the concentrations of 2,4,4'tribromo- (PBDE-28) and 2,3',4,4'-tetrabromodiphenyl ether (PBDE-66). Figures 5 and 6 show the score plots of the profiles of the seven PBDEs. 


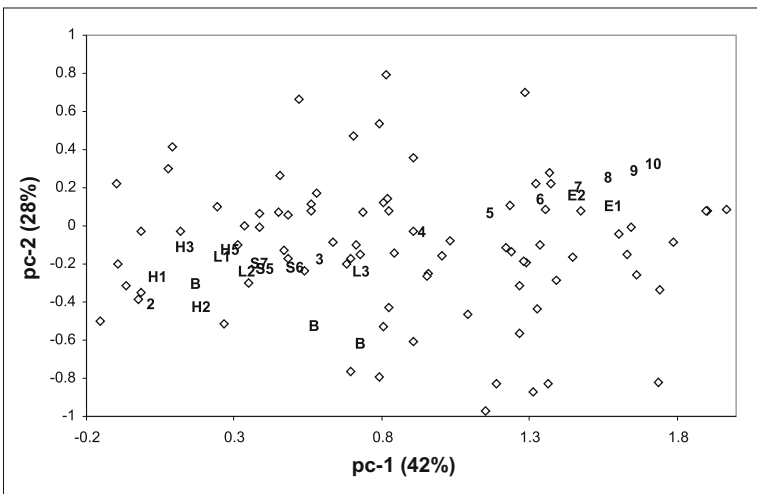

Figure 3 Expanded section of Figure 1. Points marked by alphanumeric characters are PBDE profiles of specific samples, $\diamond$ are PBDE profiles of other fish.

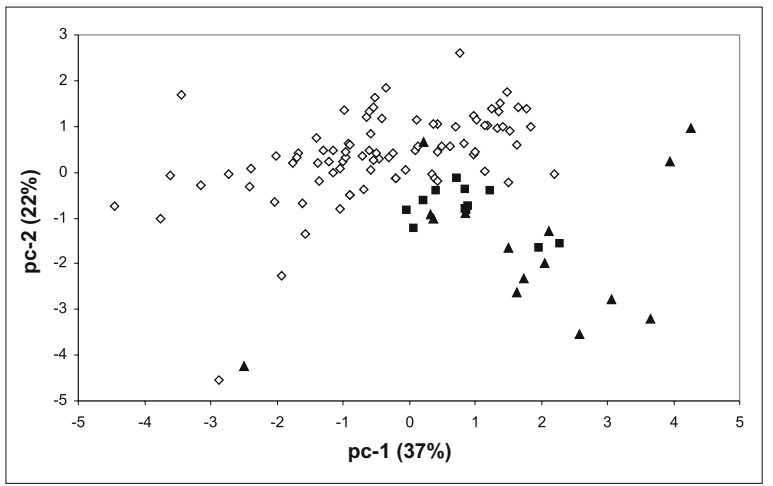

Figure 5 Profiles of PBDEs 28, 47, 66, 100, 99, 154, and 153 in the plane of the principal components $1 \& 2$. Profiles in the fish from the Baltic (1) $\square$, Great Lakes (9) $\diamond$, and crustaceans from Brittany and Normandy (15) $\boldsymbol{\Delta}$

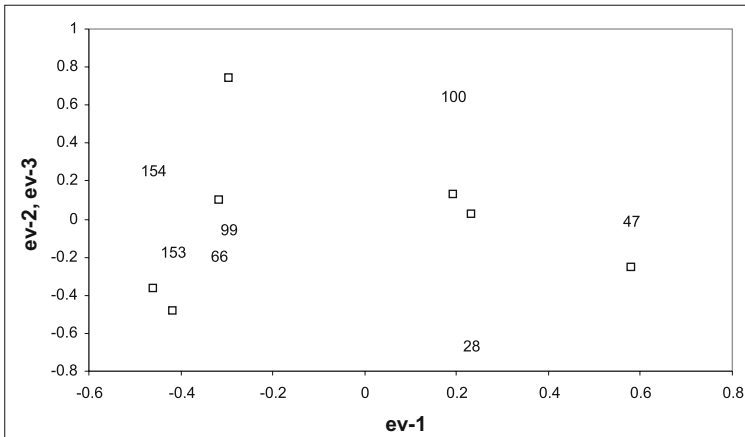

Figure 7 Loading plot of PBDEs 28, 47, 66, 100, 99, 154, and 153 on the principal components $p c-1$ (ev-1), pc-2 (ev-2), and pc-3 (ev-3, 口). The ev-2 values are marked by congener number.

The corresponding loading plot is in Figure 7. Because of the increased number of congeners, three principal components account for $77 \%$ of the original variation of the data. The score plots show that the PBDE profiles of the Baltic fish again form a cluster, somewhat separated from the profiles of the Great Lakes fish. The PBDE profile of the crustaceans is

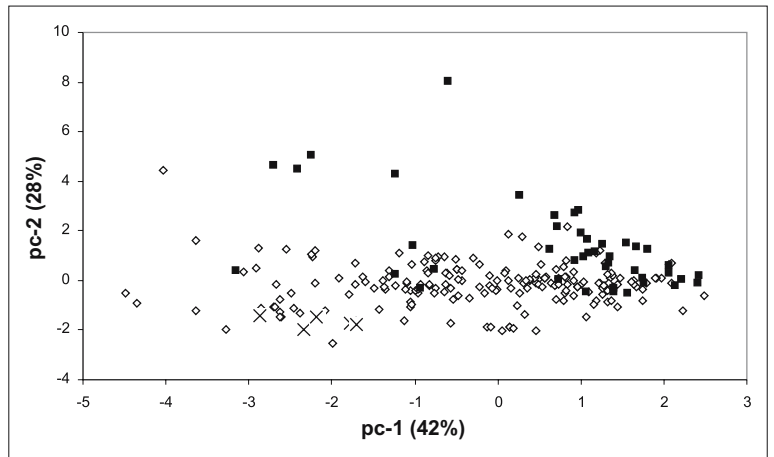

Figure 4 Profiles of PBDEs 47, 100, 99, 154, and 153 in the plane principal components pc-1 \& pc-2 ("score plot"). Same as Figure 1, but with highlighted profiles of California fish.

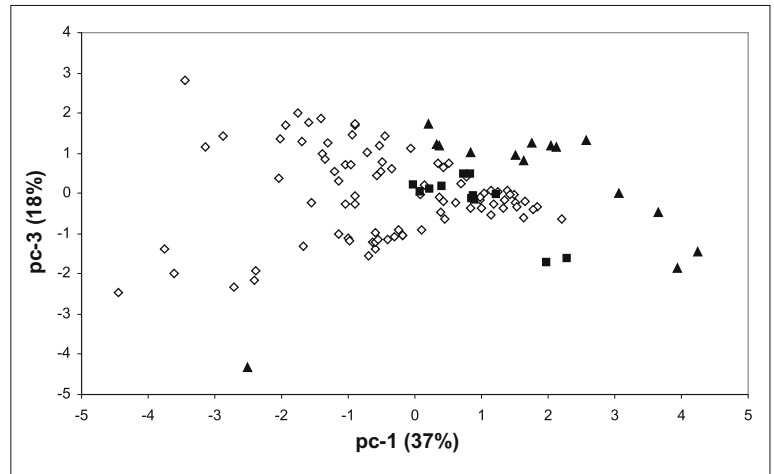

Figure 6 Profiles of PBDEs 28, 47, 66, 100, 99, 154, and 153 in the plane of the principal components $1 \& 3$. For details see Figure 5.

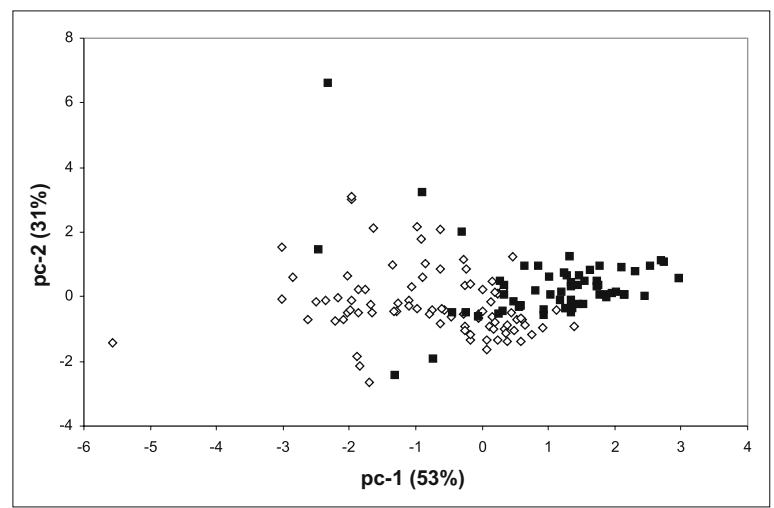

Figure 8 Profiles of four PBDEs (47, 100, 99, and 153) in lake trout and walleye from the Great Lakes in the plane of the principal component $1 \& 2$. Symbol $\diamond$ denotes data by Zhu and Hites (9), data by Batterman et al. (16).

different from the fish, possibly because of metabolic differences. The score plots also show that all data contain some outliers. It is not possible to tell whether these are real, analytical, or other artifacts. In any case, they confirm the value of PCA in visualising the structure of the data. 
Batterman et al.(16) reported the concentrations of four PBDEs $(44,99,100$, and 153) in lake trout and walleye from the Great Lakes, caught mostly between 1980 and 2000 . This provided an opportunity to compare their results with those reported by Zhou and Hites (18) for the same species, same locations, and same period. Figure 8 shows profiles (16) with generally higher pc-1 values (higher proportions of PBDE-47). In addition, the concentrations reported by Zhou and Hites (18) are much higher than those reported by Batterman et al. (16) (Table 3). This indicates a systematic bias between the two laboratories.

The average total mass fractions of PBDEs (sums of five congeners) in the studied fish samples range from $0.62 \mathrm{ng} \mathrm{g}^{-1}$ wet weight to $89.7 \mathrm{ng} \mathrm{g}^{-1}$ wet weight, and the single data set for crustaceans has an average total mass fraction of $0.223 \mathrm{ng} \mathrm{g}^{-1}$ wet weight. Table 3 indicates that the PBDE profile may change with the sum of PBDEs. For example, the proportion of the PBDE- 47 is $55.6 \%$ at the total mass fraction of $57.2 \mathrm{ng} \mathrm{g}^{-1}$ wet weight, and $61 \%$ to $65 \%$ at mass fractions of (0.6 to 1.7$) \mathrm{ng} \mathrm{g}^{-1}$ wet weight. However, species (eel) and tissue (liver) also play a role. As mentioned above, the differences in both profiles and total mass fractions, reported for the same species and locations by different laboratories, raise some concern. PBDEs mass fractions (sum of 19 congeners) in Estonian fish (1) are very low (Table 4). Since the concentration of PBDEs in the air in Estonia and in the UK are within the same range (Table 3), air does not seem to be the main input route of PBDEs into the aquatic environment in Estonia.

\section{CONCLUSION}

PBDE-47 and to some extent PBDEs 100 and 153 are much more abundant in the aquatic biota than in commercial formulations. This may be attributed to the stability of PBDE-47, to its possible formation from more brominated PBDEs (18), and to higher lipophilicity and stability of PBDEs 100 and 153. However, these data do not provide sufficient information about the relations between the PBDE profiles and the locations, species, the age of the aquatic fauna, and the total level of PBDEs. There appear to be differences between regions (California, Baltic, and other locations), species (fish vs crustaceans), and organs (muscle, liver). Some of the differences may be caused by different local uses of commercial PBDE formulations and different input routes, but there is an indication that the profiles change with the age of the Baltic herring. In addition, there are systematic interlaboratory differences for the same fish and locations.

\section{Acknowledgement}

This project was financially supported by the Ministry of Agriculture of Estonia (samples collection), by the National Public Health Institute, Department of Environmental Health, Laboratory of Chemistry (PBDE analyses), and by the Ministry of Education of Estonia Target Funding SF0180104s08.

Table 1 Extreme profiles in Figure 1 (clockwise from 12)

\begin{tabular}{cccccc}
\hline PBDE-47 & PBDE-100 & PBDE-99 & PBDE-154 & PBDE-153 & \\
\hline 34.72 & 4.58 & 8.51 & 49.90 & 2.29 & Lake trout, Hites (8) ref.80 \\
82.18 & 11.88 & 3.96 & 0.99 & 0.99 & Wild coho, Zitko (4) \\
42.24 & 3.11 & 48.45 & 3.11 & 3.11 & Large eels, des Jardines Anderson \\
29.41 & 8.14 & 34.39 & 8.60 & 19.46 & Catfish, Minh et al. (10) \\
\hline
\end{tabular}

Table 2 Extreme profiles of California fish (14) in Figure 3 (clockwise from 12)

\begin{tabular}{cccccc}
\hline PBDE-47 & PBDE-100 & PBDE-99 & PBDE-154 & PBDE-153 & \\
\hline 1.66 & 89.66 & 2.11 & 2.57 & 4.00 & Speckled sanddab, Eureka \\
79.10 & 16.27 & 0.86 & 3.16 & 0.61 & White surf perch, Long Beach \\
25.59 & 19.58 & 37.90 & 8.95 & 7.97 & Jacksmelt, Oakland \\
\hline
\end{tabular}


Table 3 Mass fractions ( $w / \mathrm{ng} \mathrm{g}^{-1}$ wet weight) and profiles (\%) of PBDEs in fish, crustaceans and sewage sludge; and concentrations $\left(\gamma / \mathrm{pg} \mathrm{m}^{-3}\right)$ and profiles (\%) of PBDEs in air

\begin{tabular}{lcccccccc}
\hline Sample & & PBDE-47 & PBDE-100 & PBDE-99 & PBDE-154 & PBDE-153 & Sum & Reference \\
\hline Herring & $\mathrm{w}$ & 0.38 & 0.08 & 0.10 & 0.04 & 0.02 & 0.62 & $(1)$ \\
& $\%$ & 61.25 & 12.25 & 16.54 & 5.95 & 4.00 & & \\
\hline Sprat & $\mathrm{w}$ & 0.43 & 0.09 & 0.10 & 0.04 & 0.03 & 0.68 & $(1)$ \\
& $\%$ & 63.54 & 12.73 & 14.55 & 5.34 & 3.84 & & \\
\hline Eel & $\mathrm{w}$ & 0.53 & 0.08 & 0.02 & 0.05 & 0.02 & 0.70 & $(1)$ \\
& $\%$ & 75.63 & 11.14 & 3.55 & 7.33 & 2.34 & & \\
\hline Lamprey & $\mathrm{w}$ & 1.12 & 0.25 & 0.30 & 0.09 & 0.05 & 1.81 & $(1)$ \\
& $\%$ & 62.02 & 13.76 & 16.36 & 5.12 & 2.73 & & \\
\hline Herring & $\mathrm{w}$ & 1.04 & 0.25 & 0.12 & 0.07 & 0.02 & 1.50 & $(5)$ \\
& $\%$ & 69.44 & 16.36 & 8.23 & 4.44 & 1.52 & & \\
\hline Misc fish muscle & $\mathrm{w}$ & 1.09 & 0.28 & 0.16 & 0.09 & 0.05 & 1.67 & $(7)$ \\
& $\%$ & 65.15 & 16.96 & 9.77 & 5.27 & 2.85 & & \\
\hline Misc fish liver & $\mathrm{w}$ & 56.54 & 13.18 & 13.64 & 3.67 & 2.71 & 89.7 & $(7)$ \\
& $\%$ & 63.01 & 14.69 & 15.20 & 4.09 & 3.02 & & \\
\hline Lake trout $\mathcal{E}$ walleye & $\mathrm{w}$ & 31.79 & 7.64 & 10.89 & 4.32 & 2.53 & 57.2 & $(9)$ \\
& $\%$ & 55.60 & 13.37 & 19.05 & 7.56 & 4.42 & & \\
\hline Farmed salmon & $\mathrm{w}$ & 0.67 & 0.15 & 0.13 & 0.05 & 0.04 & 1.03 & $(11)$ \\
& $\%$ & 64.58 & 14.51 & 12.29 & 4.70 & 3.92 & & \\
\hline Misc fish & $\mathrm{w}$ & 2.49 & 1.35 & 0.47 & 0.43 & 0.14 & 4.87 & $(14)$ \\
& $\%$ & 51.12 & 27.68 & 9.55 & 8.87 & 2.78 & & \\
\hline Crustaceans & $\mathrm{w}$ & 0.178 & 0.029 & 0.006 & 0.008 & 0.002 & 0.223 & $(15)$ \\
& $\%$ & 79.88 & 12.97 & 2.64 & 3.57 & 0.93 & & \\
\hline Lake trout $\&$ walleye & $\mathrm{w}$ & 31.79 & 7.64 & 10.89 & & 2.53 & 52.8 & $(9)$ \\
& $\%$ & 60.15 & 14.46 & 20.60 & & 4.78 & & \\
\hline Lake trout $\&$ walleye & $\mathrm{w}$ & 24.81 & 3.88 & 4.07 & & 1.50 & 34.26 & $(16)$ \\
& $\%$ & 72.42 & 11.32 & 11.89 & & 4.38 & & \\
\hline Air, Lahemaa & $\gamma$ & 12.07 & 4.42 & 25.29 & 2.10 & 2.87 & 46.75 & $(17)$ \\
& $\%$ & 25.8 & 9.45 & 54.1 & 4.49 & 6.14 & & \\
\hline Air & $\gamma$ & 7.70 & 1.30 & 5.30 & 1.70 & 2.90 & 18.00 & $(19)$ \\
\hline & $\%$ & 40.74 & 6.88 & 28.04 & 8.99 & 15.34 & & \\
\hline
\end{tabular}

Table 4 Content of PBDEs in Estonian wild fish from the Baltic Sea in 2006.

\begin{tabular}{|c|c|c|c|}
\hline Wild fish & & Number of samples & $\begin{array}{c}\text { Sum of PBDEs } / \mathrm{ng} \mathrm{g}^{-1} \text { fresh weight } \\
\text { range }\end{array}$ \\
\hline \multirow[t]{3}{*}{ Baltic herring } & Lowerbound & 4 & $0.65-0.85$ \\
\hline & Mediumbound & & $0.66-0.86$ \\
\hline & Upperbound & & $0.67-0.86$ \\
\hline \multirow[t]{3}{*}{ Baltic sprat } & Lowerbound & 3 & $0.87-0.92$ \\
\hline & Mediumbound & & $0.88-0.94$ \\
\hline & Upperbound & & $0.90-0.95$ \\
\hline \multirow[t]{3}{*}{ Eel } & Lowerbound & 2 & $0.91-1.26$ \\
\hline & Mediumbound & & $0.97-1.32$ \\
\hline & Upperbound & & $1.03-1.37$ \\
\hline \multirow[t]{3}{*}{ Lamprey } & Lowerbound & 3 & $1.95-2.25$ \\
\hline & Mediumbound & & $1.99-2.27$ \\
\hline & Upperbound & & $2.02-2.30$ \\
\hline
\end{tabular}




\section{REFERENCES}

1. Roots O, Kiviranta H, Rantakokko P. PBDE levels in Estonian foodstuffs. Organohal Compounds 2007;69:2339-41.

2. Kiviranta H, Ovaskainen M-L, Vartiainen T. Market basket study on dietary intake of PCDD/Fs, PCBs, and PBDEs in Finland. Environ Int 2004;30:923-32.

3. Roots O, Zitko V, Simm M. Trends of polychlorinated dibenzo-p-dioxins (PCDDs), dibenzofurans (PCDFs) and dioxin-like polychlorinated biphenyls (DL-PCBs) in Baltic herring. Fresenius Environ Bull 2007;16:112630.

4. Zitko V. Profiles of organohalogen compounds in cultured and wild fish [displayed 29 September 2003]. Available at http://preprint.chemweb.com/ envchem/0309004.

5. Parmanne R, Hallikainen A, Isosaari P, Kiviranta $H$, Koistinen J, Laine O, Rantakokko P, Vuorinen PJ, Vartiainen T. The dependence of organohalogen compound concentrations on herring age and size in the Bothnian Sea, northern Baltic. Mar Pollut Bull 2006;52:149-61.

6. La Guardia MJ, Hale RC, Harvey E. Detailed polybrominated diphenyl ether (PBDE) congener composition of the widely used Penta-, Octa-, and Deca-PBDE technical flame-retardant mixtures. Environ Sci Technol 2006;40:6247-54.

7. Voorspols S, Covaci A, Schepens P. Polybrominated diphenyl ethers in marine species from the Belgian North Sea and the Western Scheldt Estuary: Levels, profiles, and distribution. Environ Sci Technol 2003;37:4348-57.

8. Hites RA. Polybrominated diphenyl ethers in the environment and in people: A meta-analysis of concentrations. Environ Sci Technol 2004;38:94556.

9. Zhu LY, Hites RA. Temporal trends and spatial distributions of brominated flame retardants in archived trout from the Great Lakes. Environ Sci Technol 2004;38:2779-84.
10. Minh NH, Minh TB, Kajiwara N, Kunisue T, Iwata H, Viet PH, Tu NPC, Tuyen BC, Tanabe S. Contamination by polybrominated diphenyl ethers and persistent organochlorines in catfish and feed from Mekong River Delta, Vietnam. Environ Toxicol Chem 2006;25:27009.

11. Montory M, Barra R. Preliminary date on polybrominated diphenyl ethers (PBDEs) in farmed fish tissues (Salmo salar) and fish feed in Southern Chile. Chemosphere 2006;63:1252-60.

12. desJardins Anderson T, MacRae JD. Polybrominated diphenyl ethers in fish and wastewater samples from an area of the Penobscot River in Central Maine. Chemosphere 2006;62:1153-60.

13. Hajšlová J, Pulkrabová J, Poustka J, Čajka T, Randák T. Brominated flame retardants and related chlorinated persistent organic pollutants in fish from river Elbe and its main tributary Vltava. Chemosphere 2007;69:1195203.

14. Brown FR, Winkler J, Visita P, Dhaliwal J, Petreas M. Levels of PBDEs, PCDDs, PCDFs, and coplanar PCBs in edible fish from California coastal waters. Chemosphere 2006;64:276-86.

15. Bodin N, Abarnou A, Fraisse D, Defour S, Loizea V, Le Guellec A-M, Philippon X. PCB, PCDD/F and PBDE levels and profiles in crustaceans from the coastal waters of Brittany and Normandy (France). Mar Pollut Bull 2007;54:657-68.

16. Batterman S, Chernyak S, Gwynn E, Cantonwine D, Jia C, Begnoche L, Hickey JP. Trends of brominated diphenyl ethers in fresh and archived Great Lakes fish (1979-2005). Chemosphere 2007;69:444-57.

17. Roots O, Sweetman A. Passive air sampling of persistent organic pollutants in two Estonian air monitoring stations. Oil Shale 2007;24:483-94.

18. Zhao YY, Tao FM, Zeng EY. Theoretical study on the chemical properties of polybrominated diphenyl ethers. Chemosphere 2008;70:901-7.

19. Harrad S, Wijesekera R, Hunter S. Halliwell C, Baker R. Preliminary assessment of U.K. human dietary and inhalation exposure to polybrominated diphenyl ethers. Environ Sci Technol 2004;38: 2345-50. 


\section{Sažetak}

\section{SASTAV POLIBROMIRANIH DIFENIL-ETERA U VODENOJ BIOTI}

Sastav polibromiranih difenil-etera u vodenoj fauni razlikuje se od onih u komercijalnim formulacijama, ponajviše po mnogo većem udjelu kongenera 47. Osim toga različiti autori opisuju bitno različite značajke, a da pritom nisu vidljivi nikakvi obrasci vezani uz vrstu, lokaciju i sl. Izgleda da tomu pridonose sustavne razlike među laboratorijima i pogreške u mjerenju unutar samih laboratorija. Međutim, sastav polibromiranih difenil-etera u baltičkoj ribi vrlo je sličan i čini blisko povezanu skupinu. Polibromirani difenil-eteri u rakova različiti su od onih u riba.

KLJUČNE RIJEČI: Baltičko more, PBDE, PBDE-47, rakovi, ribe, Velika jezera

\section{CORRESPONDING AUTHOR:}

Ott Roots, PhD

Estonian Environmental Research Institute

Marja 4D, 10617 Tallinn, Estonia

E-mail: ott.roots@klab.ee 